DOI: $10.5613 /$ rzs.44.1.5

Mark Banks, Rosalind Gill, Stephanie Taylor (eds)

\section{Theorizing Cultural Work: Labour, Continuity and Change in the Cultural and Creative Industries}

London - New York: Routledge, 2013, 206 str.

U posljednjih nekoliko godina dogodio se svojevrstan procvat proučavanja rada u kulturi (kulturnog rada), kreativnog rada, kao i rada i zaposlenosti u medijima. Međutim, unutar tog novog korpusa istraživačkih radova pokazalo se da, s jedne strane, nedostaje historijski uvid $\mathrm{u}$ promjene rada u kulturi i medijima, dok s druge strane nedostaje snažnija (ponovna) teoretizacija ovog područja istraživanja. Upravo zbornik Theorizing Cultural Work: Labour, Continuity and Change in the Cultural and Creative Industries što su ga uredili Mark Banks Rosalind Gill i Stephanie Taylor, u izdanju britanskog Centra za istraživanje sociokulturnih promjena (CRESC), pruža važan doprinos razumijevanju širega povijesnog i društvenog konteksta (promjene) rada u kulturnim i kreativnim industrijama.

Zbornik sadržava četrnaest priloga koji su, osim uvodnoga poglavlja, podijeljeni u tri dijela - »Histories« (»Povijesti«), »Specificities/Transformations«
(»Posebnosti/transformacije $\ll$ ) te $» F u-$ tures« (»Budućnosti«). Uz uvodni tekst urednika i urednica tu je dvanaest radova te intervju s američkim teoretičarem kulture i medija Andrewom Rossom. U prvom dijelu predstavljeni su radovi koji pokazuju kako »kulturni rad« nije tolika novost kao što se posljednjih nekoliko godina pokušava prikazati $\mathrm{u}$ znanstvenom i javnopolitičkom (policy) diskursu. Tako Susan Luckman podsjeća na kontinuitet prekarnosti kulturnog rada za vrijeme pokreta Arts and Crafts u viktorijanskoj Engleskoj. Autorica pokazuje da ideje viktorijanskog socijalizma koje su promovirali John Russell i William Morris nisu toliko utopijske i romantičarske kako su mnogi autori/ce tvrdili, nego da se u njihovoj srži nalazi »stremljenje za smislenim radom«, a koje možemo naći u većini suvremenih rasprava o kulturnom i kreativnom radu. U sljedećem prilogu Sarah Brouillette pokazuje kako imidž umjetnika/ce kao "primjerenoga kreativnog radnika/ce« nema samo svoj izvor $\mathrm{u}$ devetnaestostoljetnom viktorijanskom kontekstu, nego (ponovno) biva aktualiziranim u radovima američkih psihologa sredinom dvadesetog stoljeća o »novim protokulturnim radnicima« - Millsovim »bijelim ovratnicima« koji će kreativnost svakog/e radnika/ce postaviti kao normu za »kapitalizam budućnosti«. $\mathrm{Na}$ sličan način Bridget Conor ukazuje na kontinuitet ranjive pozicije kulturnih radnika/ca, točnije scenarista/ice, kroz 
povijest hollywoodske filmske i televizijske produkcije pri čemu scenaristi/ce koriste tu "povijest ranjivosti profesije« kako bi, s jedne strane, racionalizirali vlastitu poziciju, a s druge strane uputili na opravdanost određenih trenutačnih strategija za smanjenje poteškoća $\mathrm{u}$ radu. $\mathrm{U}$ posljednjem prilogu prvog dijela zbornika Kate Oakley razmatra status rada i zaposlenosti kroz analizu povijesti radničkog pokreta $\mathrm{i}$ ljevice $\mathrm{u}$ Ujedinjenom Kraljevstvu. Oakley pokazuje kako su mnogi zagovaratelji/ce razvoja kulturnih industrija na lokalnoj i regionalnoj razini ujedno zagovarali ideju kulturnog rada kao »dobrog rada«. No, kad se analiziraju rezultati javnopolitičkih instrumenata za koje su se oni zalagali, može se primijetiti da su zanemarivana upravo pitanja klase i rada, što je rezultiralo time da su u kulturnom sektoru u UK-u radni uvjeti loši i da sam sektor nije dovoljno snažan, pri čemu Oakley pokazuje kako je to dio šire politike izbacivanja pitanja radnih prava iz javnih politika, medija, te javnog diskursa uopće.

Drugi dio zbornika razmatra koliko možemo govoriti o posebnostima kulturnog i kreativnog rada $\mathrm{u}$ odnosu na druge tipove rada, zatim koje bi bile značajke te "posebnosti«, pružajući istodobno uvid u kontekst dinamičnih društvenih, tehnoloških i globalnih transformacija kojima je kulturni i kreativni rad izložen u posljednjih nekoliko godina. Tekst Matta Stahla pokazuje kako posebnost kulturnog rada nije u njegovu razlikovanju od drugih vidova rada, nego u njegovu potencijalu »idealnog mo- dela « za ostale tipove rada. Komparirajući određene elemente angloameričke $i$ njemačke povijesti rada, Stahl otkriva koje su sve mogućnosti »čitanja« kako kulturnoga tako i nekulturnoga rada te koliko određeni kontekst određuje što je »idealan rad« kojem trebamo stremiti. Na sličan način i Jason Toynbee u svom članku želi kulturni rad »spustiti s trona« te dokazati kako se slične transformacije rada zbivaju i u ostalim područjima. Međutim, spominje i to kako kulturni rad ipak ima neke karakteristike koje ne postoje u ostalim vidovima rada, ali su značajne za rad u cjelini. Toynbee naglašava kako upravo kulturne industrije inzistiranjem na konceptu "posebnosti« kulturnog rada pridonose eksploataciji radnika/ca. Prilog Bretta Neilsona postavlja niz političkih pitanja vezanih uz "prekarnost« kulturnog rada i traži od nas da se zamislimo nad širom mrežom odnosa o kojima ovisi razvoj globalnih kulturnih industrija. Neilson ističe potrebu za propitivanjem postojećih mreža odnosa eksploatacije u radnim procesima koji omogućuju kulturni rad i stvaranjem novih (fluidnih) oblika solidarnosti. Na tragu je potrebe za solidarnošću i članak Richarda Maxwella i Tobyja Millera koji upozorava kako nije dovoljno samo analizirati i upozoravati na probleme tzv. $»$ kreativnog kognitarijata«, nego treba analizirati sav rad koji pridonosi stvaranju određenoga kulturnog proizvoda ili usluge. Tako Maxwell i Miller analiziraju položaj radnika/ca u tvrtkama podugovarača Applea te pokazuju težak materijalni položaj onih koji su zaslužni 
za nastanak alata kulturnog i kreativnog rada. U posljednjem prilogu drugoga dijela zbornika Melissa Gregg propituje "posebnost« kulturnog rada kroz propitivanje rušenja granica između radnog vremena i dokolice (ponajprije posredstvom online alata), pri čemu slobodno vrijeme i intimna sfera bivaju kolonizirani radom, čime pokazuje da stvaranje radnih politika kroz odvajanje tih dviju sfera više nije moguće.

Treći dio zbornika posvećen je razmatranjima mogućih budućih scenarija za razvoj kulturnog i kreativnog rada pri čemu je središnje pitanje nadilaženje rodne i klasne nejednakosti. Sarah B. Proctor-Thomson kritički sagledava diskurs o rodnoj raznolikosti u kulturnim industrijama te upozorava kako se u javnopolitičkom diskursu o kulturnim i kreativnim industrijama u Ujedinjenom Kraljevstvu povezuje rodna raznolikost $\mathrm{s}$ pozitivnim ekonomskim rezultatima, iako istraživanja pokazuju kontinuiranu podzastupljenost žena u kulturnim industrijama, a tamo gdje ih ima najčešće su »poticateljice kreativnosti« a ne same »kreativke«. Proctor-Thomson tako ističe kako se i progresivne ideje i javnopolitički instrumenti mogu koristiti kako bi se dalje produbljivale postojeće nejednakosti. U sljedećem prilogu Lisa Adkins propituje metodu osobne povijesti kao najčešće korištenu metodu za prikupljanje podataka u proučavanju kulturnog rada. Ističe potrebu za drukčijim metodološkim pristupom koji bi bio okrenut »događaju« (event) kako bi bolje odgovarao postfordističkoj proizvodnji te nestrukturiranosti karijera kulturnih radnika/ca, što, primjerice, metoda osobne povijesti ne može zahvatiti. Za razliku od Stahla i Toynbeeja iz prethodnog dijela, Mark Deuze i Nicky Lewis zalažu se za tezu o posebnosti kulturnog rada te pokazuju kako obrasci rada u kulturnim i kreativnim industrijama uistinu predstavljaju prekid s prijašnjim obrascima, čime kulturni radnik/ca postaje primjerom radnika/ce »novog radnog doba«. Posljednji prilog u zborniku je intervju s Andrewom Rossom gdje Ross upozorava na različite razine nejednakosti u spomenutom sektoru kao i na negativne tendencije kojima neplaćeni i potplaćeni rad u kulturnim i kreativnim industrijama postaje normom na globalnoj razini. Bez obzira na mnoge negativne posljedice »trenda kreativnosti« devedesetih godina, Ross smatra da je jedna od ključnih pozitivnih posljedica porast svjesnosti kulturnih radnika/ca o vlastitim radnim uvjetima i njihovo propitivanje ovisnosti o korporativnim i političkim elitama.

Uz određenu neujednačenost razine priloga u zborniku, koji nije samo ograničen na izvorne znanstvene te pregledne radove, nego uključuje i intervju, može se reći kako je ovaj zbornik radova važan prilog za razumijevanje kompleksnosti različitih pristupa kulturnom i kreativnom radu. Ponajprije, naglasak je stavljen na radove koji istražuju nejednakosti i nesigurnosti kreativnog rada u kontekstu sveopće "prekarnosti« rada, a koji je u kulturnim i kreativnim industrijama vidljiv i kroz porast neplaćenoga, potplaćenog i (samo)izrabljuju- 
ćeg rada. Potom, kroz radove posvećeDOI: $10.5613 /$ rzs.44.1.6 ne povijesnoj dimenziji upućuje se na kontinuitete u značajkama kulturnog i kreativnog rada na što se često zaboravlja. Osim toga, autori/ce ističu i snažan utjecaj informacijsko-komunikacijskih tehnologija na stvaranje novih publika, novog broja (su)kreatora, dakle sveukupno veću mogućnost uključivanja većeg broja aktera u radne procese, ali ujedno i na veće mogućnosti kontrole toga rada, i nove vidove »eksploatacije« tako proizvedenih sadržaja. I konačno, u knjizi se upozorava i na nedostatke $u$ dosadašnjim metodološkim pristupima istraživanju kulturnog i kreativnog rada te se posljedično naglašava potreba za iznalaženjem novih istraživačkih postupaka. Treba na kraju spomenuti i to da su urednici uputili i na moguće nove oblike udruživanja zaposlenih u ovom području. Neki od tih oblika udruživanja zacijelo će pridonijeti i smanjivanju postojećih rodnih, klasnih, etničkih i »rasnih« nejednakosti te će doprinijeti stvaranju održivih modela kulturnog rada u budućnosti.

Jaka Primorac Institut za razvoj $i$ međunarodne odnose, Zagreb

\section{Sabrina P. Ramet (ed.) \\ Religion and Politics in Post-Socialist Central and Southeastern Europe: Challenges since 1989}

Basingstoke: Palgrave Macmillan, 2014, 336 str.

Religion and Politics in Post-Socialist Central and Southeastern Europe: Challenges since 1989 (Religija $i$ politika u postsocijalističkoj srednjoj $i$ jugoistočnoj Europi: izazovi nakon 1989.), nova knjiga koju je uredila Sabrina P. Ramet, razmatra izazove postsocijalističkih zemalja koje je prouzročilo političko uključivanje religijskih institucija. Njezin sadržaj obuhvaća dvanaest poglavlja, pogovor, reference za daljnje čitanje te kazalo imena i pojmova.

U uvodnom poglavlju »Religious Organizations in Post-Communist Central and Southeastern Europe: An Introduction« Sabrina P. Ramet razmatra uzroke raspada komunizma, društvene i religijske promjene te političko favoriziranje tradicionalnih i dominantnih crkvi. Papin poziv na reevangelizaciju, potaknut promjenama u legislativi i ponašanju (razvod, pobačaj, kontracepcija, istospolni odnosi i zajednice), doveo je do limitiranog uspjeha kod pobačaja i istospolnih odnosa i zajednica (izražena homofobija i neprijateljstvo tijekom gay prideova), ali i do simboličkog oblika gigantomanije u gradnji vjerskih objekata. U suvremenom kontekstu društva 